\title{
Does the upwelling phenomenon influence the population dynamics and management of the seabob shrimp Xiphopenaeus kroyeri (Heller, 1862) (Crustacea, Penaeidae)?
}

\author{
T. M. Davanso • G. L. Hirose • D. R. Herrera • A. Fransozo • R. C. Costa
}

Received: 13 December 2016/Revised: 25 February 2017/Accepted: 1 March 2017/Published online: 10 March 2017

(C) Springer International Publishing Switzerland 2017

\begin{abstract}
The seabob shrimp Xiphopenaeus kroyeri ranks third in commercial importance among fisheries in southeastern Brazil. An important management question is whether the same offseason can be applied to different regions. The population dynamics of the seabob shrimp was compared in two regions of southeastern Brazil: Macaé, state of Rio de Janeiro and Ubatuba, state of São Paulo. All demographic categories of shrimp in the Macaé region were larger than those in the Ubatuba region. Lower temperatures and greater longevities in the Macaé region may account for this difference in size from Ubatuba. In Macaé, number of reproductive females and juveniles correlated with organic-matter content. In Ubatuba,
\end{abstract}

Handling editor: Vasilis Valavanis

T. M. Davanso $(\varangle) \cdot$ D. R. Herrera - R. C. Costa

Laboratório de Biologia de Camarões Marinhos e de Água

Doce (LABCAM), Depto de Ciências Biológicas,

Universidade Estadual Paulista (UNESP), Av. Eng. Luiz

Edmundo Corrijo Coube, 14-01, Vargem Limpa,

17033-360 Bauru, SP, Brazil

e-mail: tdavanso@hotmail.com

G. L. Hirose

Depto de Biologia, Universidade Federal de Sergipe,

São Cristóvão, SE, Brazil

A. Fransozo

Núcleo de Estudos em Biologia, Ecologia e Cultivo de Crustáceos (NEBECC), Depto de Zoologia, Universidade Estadual Paulista (UNESP), 18618-000 Botucatu, SP, Brazil only chlorophyll-a showed a correlation with reproductive females. The reproductive period and recruitment were correlated in both populations. The difference in environmental factors between these regions, resulting of the Cabo Frio upwelling, although they are located close together, directly influences the population dynamics of $X$. kroyeri. The Cabo Frio upwelling may be acting as a physical barrier, preventing gene flow and differentiating the seabob shrimp stocks in the two regions. These data suggest that different offseason periods for different regions could increase the sustainability of shrimp harvesting along the Brazilian coast.

Keywords Decapoda - Growth - Reproduction . Upwelling · Sustainable harvesting

\section{Introduction}

One consequence of the validation of the taxon Xiphopenaeus riveti (Bouvier 1907) for the Pacific Ocean by Gusmão et al. (2006) was to restrict the known distribution of Xiphopenaeus kroyeri (Heller, 1862) to the Atlantic Ocean, from Virginia (USA) to Rio Grande do Sul (Brazil) (Costa et al., 2003). In Brazil, this shrimp is intensively exploited in a multispecies fishery, mainly due to its abundance in shallow coastal areas and its size (Costa et al., 2007). In 2010 and 2011, the Brazilian shrimp fishery 
produced around 39,000 tons annually, of which the seabob shrimp comprised 15,000 t (IBAMA, 2011). Including all fisheries in southeastern Brazil (from Espírito Santo to São Paulo states), X. kroyeri is the third most-traded species, behind only the Brazilian sardine Sardinella brasiliensis (Steindachner, 1879) and the white croaker Micropogonias furnieri (Desmarest, 1823) (Ávila-da-Silva et al., 2005). In the state of São Paulo, this shrimp is the second most-exploited species, according to the Report of Marine and Estuarine Fishery Production (Instituto de Pesca, 2012). However, according to FIPERJ (2015), the precise monitoring data in the Rio de Janeiro state are insufficient.

Due to the commercial importance of the species, most studies have focused on southern and southeastern Brazil, mainly off Ubatuba on the northern coast of São Paulo. Studies involving X. kroyeri have treated the biodiversity (Costa et al., 2000, 2003; Castilho et al., 2008; Silva et al., 2014), carcino-bycatch of the seabob shrimp fishery (Severino-Rodrigues et al., 2002; Branco and Fracasso, 2004; Robert et al., 2007), distributional ecology (Costa et al., 2007; Heckler et al. 2014a, b), population dynamics (Nakagaki \& Negreiros-Fransozo, 1998; Branco et al., 1999; Castro et al., 2005; Campos et al., 2009; Costa et al., 2011; Fernandes et al., 2011; Heckler et al., 2013; Castilho et al., 2015), substrate selection and daily activity (Simões et al., 2010; Freire et al., 2011), and population genetics (Voloch \& Sole-Cava, 2005; Gusmão et al., 2006).

Studies comparing different regions along the geographical distribution of $X$. kroyeri are still few. Voloch \& Sole-Cava (2005) compared individuals of $X$. kroyeri from three locations in southeastern Brazil (Ubatuba (SP), Cabo Frio (RJ), and Nova Almeida (ES)). The study revealed differences in genetic structure among the regions, and the Ubatuba population was significantly different from the others. The authors concluded that the São Paulo population should be considered as an independent stock from those of Rio de Janeiro and Espírito Santo, which may still form a single panmictic unit. The Cabo Frio upwelling may be acting as a physical barrier, preventing gene flow and differentiating the seabob shrimp stocks in the two regions.

Geographical differences are another aspect that requires investigation. Changes in the population dynamics of a species can also be attributed to the "paradigm of the latitudinal effect," which suggests that populations tend to have shorter spans, with smaller sizes at maturity and smaller asymptotic sizes, and the reproductive and recruitment periods lengthen as latitude decreases (Bauer, 1992; Bauer \& RiveraVega, 1992; Costa \& Fransozo, 2004; Gavio \& Boschi, 2004; Castilho et al., 2007b).

In South America, the few penaeid studies addressing this issue and comparing geographically different populations are limited to Artemesia longinaris Spence Bate 1888, including temperate, subtropical, and tropical regions (Castilho et al., 2007b; Costa et al., 2010; Semensato \& Di Beneditto, 2008). The first two studies showed the application of the paradigm comparing populations from the coast of Argentina to Ubatuba, São Paulo, Brazil. Semensato \& Di Beneditto (2008), however, found that in Rio de Janeiro, a tropical region at lower latitude, but near the upwelling area, the values of maturity, maximum sizes, and ages increased. Although the latitudinal pattern is evident for some penaeid shrimp species, local variations may also strongly influence populations. The question remains as to whether the populations of $X$. kroyeri in regions influenced by upwelling do or do not follow this pattern. Two regions were selected for this study to test the hypothesis in which local variations due to coastal upwelling could affect the structure and population dynamics of $X$. kroyeri.

The first region (Macaé, RJ) is located north of and adjacent to the Cabo Frio upwelling. Although it is a tropical area $\left(22^{\circ} 36^{\prime} \mathrm{S}\right)$, low bottom-water temperatures are recorded during most of the year, not exceeding $21^{\circ} \mathrm{C}$ (Silva et al., 2014) and reaching $12^{\circ} \mathrm{C}$ depending on the intensity of the upwelling (Voloch \& Sole-Cava, 2005). The upwelling in this area promotes the transport of nutrients $(\mathrm{N}$ and $\mathrm{P})$ from lower layers (South Atlantic Central Water, SACW) to the photic zone. This directly influences the primary productivity by the increase in phytoplankton, which is composed predominantly of diatoms (Odebrecht \& Djurfeldt, 1996; Gaeta \& Brandini, 2006; Lopes et al., 2006).

The other region chosen for this study (Ubatuba, SP) is located southwest of the Cabo Frio upwelling. This is an oligo-mesotrophic region, with moderate levels of primary productivity (chlorophyll- $a$ ) throughout the year. During spring and summer, the action of the SACW increases chlorophyll- $a$ values 
(Castro-Filho et al., 1987). The annual mean bottomwater temperature is above $23^{\circ} \mathrm{C}$ (Pantaleão et al., 2016).

A study comparing different regions in relation to latitude and environmental factors, particularly in locations close to an upwelling area, could reveal differences in the population dynamics of a species, which is essential information for fishery managers. Considering that the seabob shrimp is an important fishery resource in southeastern Brazil and the same offseason is presently imposed on the entire region, it is needful to assess whether the present closure period is appropriate. Overexploitation of a species alters the population dynamics, for example, decreasing the asymptotic size, accelerating sexual maturation, and decreasing oocyte production (Birkeland \& Dayton, 2005; Walsh et al., 2006; Fonteles-Filho, 2011). According to the established norms published by IBAMA/CEPSUL, the shrimp offseason, which includes $X$. kroyeri, extends from March 1 to May 31 each year.

The present study tested the hypothesis that the populations of $X$. kroyeri found north of and near the Cabo Frio upwelling (Macaé-RJ) and south of the upwelling region at a distance of about $1^{\circ}$ latitude (Ubatuba-SP) show different dynamics, because these populations are in different geographic regions and exposed to different environmental factors. We analyzed the population structure, relationship between the species and environmental factors, growth and longevity, reproductive periods, and recruitment of the seabob shrimp in both regions separately. We also discuss whether the same offseason period can be applied in both regions off southeastern Brazil.

\section{Materials and methods}

Study areas

Samples were collected at two sites off the southeastern Brazilian coast: Macaé-RJ, $22^{\circ} 37^{\prime} \mathrm{S}$ and $041^{\circ} 78^{\prime} \mathrm{W}$; and Ubatuba, $23^{\circ} 27^{\prime} \mathrm{S}$ and $045^{\circ} 02^{\prime} \mathrm{W}$.

The Macaé region is located off the northern coast of Rio de Janeiro state, near the Cabo Frio upwelling area. The region is surrounded by the Santana archipelago, composed of Santana Island, Francês Island, Ponta das Cavas, South Islet, and many rocks (Brasil, 1983). Northeasterly winds predominate during summer, and because of the orientation of the Rio de Janeiro coastline these winds drive the coastal water seaward, favoring the incursion and upwelling of the cold South Atlantic Central Water (SACW), which usually has temperatures below $20^{\circ} \mathrm{C}$ and high nutrient concentrations. During the winter, westerly winds dominate and coastal waters return to their usual position over the continental shelf (Emilsson, 1961; Moreira da Silva, 1977; Gonzalez-Rodriguez et al., 1992). Although the influence of the SACW is more intense in summer, the Macaé coastal area is strongly influenced by this water mass throughout the year as a result of the upwelling off Cabo Frio, resulting in low water temperatures (Valentin, 1984). At Cabo Frio, De Leo \& Pires-Vanin (2006) found bottom-water temperatures more similar to those off southern Brazil than off the southeastern coast. Sancinetti et al. (2014) observed a bottom-water temperature range of $17-26^{\circ} \mathrm{C}$ in the Macaé region over two years of sampling.

In the Ubatuba region, the coast features tiny isolated massifs and the terminal spurs of the Serra do Mar, whose characteristics result in a coastline with several semi-confined coves (Ab'Saber, 1955). This topography includes numerous beaches and coves, which form microenvironments with irregular internal limits that favor the establishment and development of the marine biota (Negreiros-Fransozo et al., 1991). This region is influenced by three water bodies, each with unique characteristics and different distributions in summer and winter: Coastal Water $(\mathrm{CW})$, with high temperatures and low salinities $\left(T>20^{\circ} \mathrm{C}\right.$ and $S<36$ ); Tropical Water (TW), with both high temperatures and salinities $\left(T>20^{\circ} \mathrm{C}\right.$ and $\left.S>36\right)$; and SACW, with both low temperatures and salinities ( $T<18^{\circ} \mathrm{C}$ and $S<36$ ) (Castro-Filho et al., 1987).

Sampling of shrimp and environmental factors

Three different areas were analyzed in each region. The locations of these areas and the sampling sites are shown in Fig. 1.

Samples were collected monthly in both regions from July 2010 through June 2011. The collection sites were marked with a GPS (Global Positioning System), and transects were defined from 5- to 15-m depths in each study area.

For Macaé, a 30-min trawl was conducted separately at 5 and $15 \mathrm{~m}$, as the local trawling area 
Fig. 1 Approximate location of the sampling points for each study area

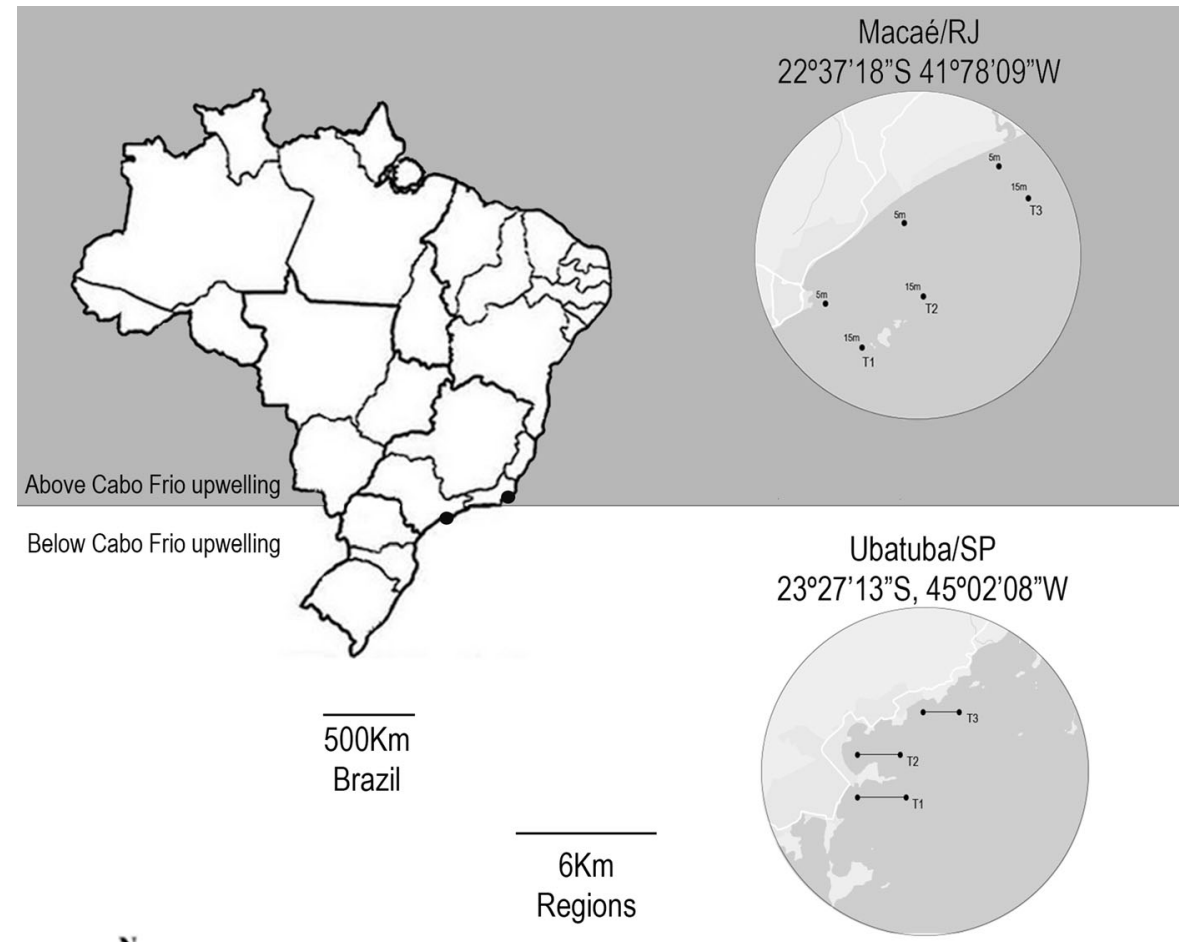

for the seabob shrimp was not known prior to the sampling. For Ubatuba, as the seabob shrimp trawling areas were already known from previous studies (Costa et al., 2007; Heckler et al., 2013), a 60-min trawl was conducted, covering a transect from 5 to $15 \mathrm{~m}$ deep at each collection point. For the analysis, the transects trawled at 5 and $15 \mathrm{~m}$ in Macaé were counted for each area separately, and thus the three different areas of each region could be compared, with a 60-min trawl each. All fieldwork was performed using a commercial fishing boat with double-rig nets $(5 \mathrm{~m}$ mouth width, mesh size $20 \mathrm{~mm}$ and $18 \mathrm{~mm}$ at the cod end).

After each trawl, shrimp were placed in labeled plastic bags and packed in coolers with crushed ice. In the laboratory, the specimens were identified to species level according to Costa et al. (2003). Individuals of $X$. kroyeri were measured for carapace length (CL), i.e., the linear distance from the postorbital angle to the posterior margin of the carapace, using calipers $(0.05 \mathrm{~mm})$. The total biomass was measured in a balance with $0.01 \mathrm{~g}$ accuracy for each trawling point. A random 400-g subsample was taken and the individuals were counted. The total number of individuals was estimated by extrapolating the subsample in relation to the total biomass, for each sampling point. When the total biomass of the sample did not exceed $400 \mathrm{~g}$, all individuals were counted and measured.

The reproductive condition of females was determined based on macroscopic observation of the gonads. Four stages of development were distinguished: $\mathrm{IM}=$ immature; $\mathrm{RU}=$ rudimentary (adults with immature gonads); ED = developing; and DE $=$ developed (Castilho et al., 2007a). For males, we examined the condition of the endopodites of the first pair of abdominal appendages: if they were separated, individuals were classified as juvenile or immature (IM); if they were united, forming the petasma, individuals were classified as adults (Boschi $\&$ Scelzo, 1977). Adult males were also classified as rudimentary (RU), when the terminal ampoules were empty; developing (ED), when the terminal ampoules were partially filled with substances; and developed (DE), when the terminal ampoules were filled with substances. 
Water temperature (mercury thermometer, ${ }^{\circ} \mathrm{C}$ ) and salinity (specific optical refractometer) were measured at all sampling points. Samples from the surface and bottom water were obtained with a Van Dorn bottle (5 L).

Surface-water samples (photic zone) were also obtained and placed in dark containers for chlorophyll- $a$ quantification. The concentration of the chlorophyll- $a$ in water $(\mu \mathrm{g} / \mathrm{L})$ was calculated following Golterman et al. (1978). A specific water volume (1.5 L) was filtered through a Millipore filter (AP40). The filter containing the material was stored at $-20^{\circ} \mathrm{C}$ until the determination. The chlorophyll- $a$ was extracted in $10 \mathrm{~mL}$ acetone $(90 \%)$, with maceration. The 10-mL extracts were transferred to test tubes and refrigerated in the dark for about $12 \mathrm{~h}$. After this period, samples were centrifuged for $10 \mathrm{~min}$ at $4900 \mathrm{rpm}$. Then, the absorbance was measured at 663 and $750 \mathrm{~nm}$, using a FEMTO 600 plus spectrophotometer.

Sediment was sampled using a Van Veen grab (area of $0.06 \mathrm{~m}^{2}$ ) in the four seasons during the study period. Each sample was placed in plastic bags, labeled with the sampling point and month, and frozen until the organic-matter analysis. The organic matter was quantified following Costa et al. (2007).

Population structure and comparisons of the size of the seabob shrimp Xiphopenaeus kroyeri (Heller, 1862) between regions

Specimens were measured and divided into 1-mm size classes. Classification into size classes optimizes the observation of cohorts in calculating the growth of individuals. Histograms were constructed in order to visually compare the frequency of the distribution of individuals in size classes, for both sexes.

Homoscedasticity (Levene test) and normality (Shapiro-Wilk test) of the data were tested. The Mann-Whitney test was used to compare the mean size of the individuals between the two regions in the following categories: total males, total females, juveniles, and adults. The same test was used to compare the mean size of males and females in the same region, with a 5\% probability level (Zar, 1999).

Growth of individuals and longevity

Growth was analyzed separately for males and females. For each sampling month, the frequency of lengths (CL) was distributed into 1-mm size classes, and modes were calculated in the "PeakFit" software (PeakFit v. 4.06 SPSS Inc. for Windows Copyright 1991-1999, AISN Software Inc.).

For the estimates of growth parameters, all the chosen cohorts were adjusted to the growth model of von Bertalanffy (1938): $\mathrm{CC}_{t}=\mathrm{CC}_{\infty}\left[1-\mathrm{e}^{-k(t-t 0)}\right]$, where the carapace length $\mathrm{CL}_{t}$ is the estimated size at age $t ; \mathrm{CL}_{\infty}$ is the asymptotic size; $k$ is the growth coefficient; and $t_{0}$ is equal to the theoretical age at which the organism would have a size of zero.

Growth parameters were estimated for the different cohorts with the "Solver" tool, varying the equation: $\mathrm{CL}_{\infty}, k$, and $t_{0}$. The selected cohorts were those with a consistent biological rhythm with respect to longevity, growth coefficient, and asymptotic size $\left(\mathrm{CL}_{\infty}\right)$. The growth curves were compared with an $F$ test $(P=0.05)$, according to Cerrato (1990). Longevity was estimated by the inverse equation of von Bertalanffy, with modifications suggested by D'Incao and Fonseca (1999), considering $t_{0}=0$ and CL/ $\mathrm{CL}_{\infty}=0.99$, and the longevity equation given by $t=\left(t_{0}-(1 / k) \operatorname{Ln}\left(1-\mathrm{CL}_{t} / \mathrm{CL}_{\infty}\right)\right)$.

Reproductive period and recruitment

The reproductive period in each population was estimated by the percentage of breeding females $(\mathrm{ED}+\mathrm{DE})$ in relation to the total of adult females, in each month or season (Castilho et al., 2007a).

The recruitment was estimated based on the monthly percentage of juvenile individuals (IM) of both sexes in relation to the total of adults. The graphs were plotted for each study area separately.

In order to investigate a possible relationship between the percentage of breeding females $(\mathrm{ED}+\mathrm{DE})$ and juveniles (males and females), we used the time-series analysis (cross-correlation Statistica 7.0, StatSoft, Inc.), with a 5\% significance level, which allows one to determine late or premature relationships ("lag") among variables (Zar, 1996; StatSoft, 2004).

Environmental factors versus juveniles and reproductive females

In order to investigate a possible relationship among environmental factors (temperature, salinity, 
chlorophyll- $a$ concentration, and organic-matter percentage in the sediment) with the percentages of juveniles (male and female) and reproductive females $(\mathrm{DE}+\mathrm{DE})$ separately, we used the time-series analysis (cross-correlation Statistica 7.0, StatSoft, Inc.), with a $5 \%$ significance level, which allows one to determine late or premature relationships ("lag") among variables (Zar, 1996; StatSoft, 2004).

\section{Results}

Environmental factors

Cooler water temperatures were recorded at Macaé (surface: $22.8 \pm 1.8^{\circ} \mathrm{C}$; bottom: $20.8 \pm 1.8^{\circ} \mathrm{C}$ ) than at Ubatuba (surface: $25.0 \pm 2.7^{\circ} \mathrm{C}$; bottom: $23.7 \pm 2.8^{\circ} \mathrm{C}$ ). Bottom-water temperatures at Macaé ranged from 18.0 to $24.5^{\circ} \mathrm{C}$ throughout the year, while at Ubatuba temperatures ranged from 19.5 to $31.0^{\circ} \mathrm{C}$ (Fig. 2). By month, the lowest mean bottom-water temperatures at Macaé were recorded in January/11 $\left(19.5 \pm 0.8^{\circ} \mathrm{C}\right)$, July/10 $\left(19.6 \pm 0.7^{\circ} \mathrm{C}\right)$, September/ $10\left(19.6 \pm 1.4^{\circ} \mathrm{C}\right)$, and February/11 $\left(19.7 \pm 1.5^{\circ} \mathrm{C}\right)$. For Ubatuba, the lowest mean bottom-water temperatures were recorded in $\mathrm{March} / 11\left(20.0 \pm 0.5^{\circ} \mathrm{C}\right)$, August $/ 10 \quad\left(21.0 \pm 0.9^{\circ} \mathrm{C}\right), \quad$ September $/ 10$ $\left(21.3 \pm 0.4^{\circ} \mathrm{C}\right)$, and June $/ 11\left(21.5 \pm 0.5^{\circ} \mathrm{C}\right)$. The highest mean bottom-water temperatures at Macaé were recorded in October/10 $\left(22.9 \pm 1.5^{\circ} \mathrm{C}\right)$, May/11 $\left(22.5 \pm 0.0^{\circ} \mathrm{C}\right)$, June $/ 11\left(21.7 \pm 0.4^{\circ} \mathrm{C}\right)$, and April/11 $\left(21.7 \pm 2.1^{\circ} \mathrm{C}\right)$. At Ubatuba, the highest mean bottom-water temperatures were recorded in February/11 $\left(28.8 \pm 2.9^{\circ} \mathrm{C}\right)$, January/11 $\left(26.8 \pm 0.8^{\circ} \mathrm{C}\right)$, December/10 $\left(26.5 \pm 1.3^{\circ} \mathrm{C}\right)$, and April/11 $\left(26.0 \pm 0.0^{\circ} \mathrm{C}\right)$.

The smallest temperature differences between the surface and bottom water were observed in August/10 $\left(0.1^{\circ} \mathrm{C}\right)$, June/11 $\left(0.3^{\circ} \mathrm{C}\right)$, May/11 $\left(0.7^{\circ} \mathrm{C}\right)$, and October $/ 10\left(0.8^{\circ} \mathrm{C}\right)$ at Macaé; and in December $/ 10\left(0.2^{\circ} \mathrm{C}\right)$, June/11 $\left(0.2^{\circ} \mathrm{C}\right)$, September/10 $\left(0.5^{\circ} \mathrm{C}\right)$, and July/10 $\left(0.7^{\circ} \mathrm{C}\right)$ at Ubatuba. The largest temperature differences were observed in March $/ 11\left(4.5^{\circ} \mathrm{C}\right)$, November/ $10\left(3.8^{\circ} \mathrm{C}\right)$, December/10 $\left(3.5^{\circ} \mathrm{C}\right)$, and February/11 $\left(3.5^{\circ} \mathrm{C}\right)$ at Macaé; and in March/11 $\left(4.5^{\circ} \mathrm{C}\right)$, January/ $11\left(2.5^{\circ} \mathrm{C}\right)$, February $/ 11\left(1.4^{\circ} \mathrm{C}\right)$, and November/10 $\left(1.2^{\circ} \mathrm{C}\right)$ at Ubatuba. At both locations, three of the four months with the largest temperature differences coincided.
Higher salinities of both surface and bottom water were recorded at Macaé (mean $36.4 \pm 1.4$ ), compared to Ubatuba (mean $36.9 \pm 0.8$ ), ranging from 29.0 to 39.0 at the surface and from 35.0 to 39.0 at the bottom. For Ubatuba, the salinities of surface water ranged from 30.0 to 35.0 and for bottom water from 29.0 to 36.0 , with means of $32.7 \pm 1.8$ and $33.5 \pm 1.8$ for surface and bottom, respectively.

The mean concentration of chlorophyll- $a$ in Macaé was $2.25 \pm 2.67 \mu \mathrm{g} / \mathrm{L}$, ranging from 0.32 to $14.80 \mathrm{~g} /$ $\mathrm{L}$ during the year. In contrast, Ubatuba showed lower chlorophyll- $a$ concentrations during the year, with a mean concentration of $0.63 \pm 0.56 \mu \mathrm{g} / \mathrm{L}$, ranging from 0.03 to $2.03 \mu \mathrm{g} / \mathrm{L}$. By month, the highest mean values of chlorophyll- $a$ at Macaé were recorded in January/11 $\quad(6.84 \pm 6.99 \mu \mathrm{g} / \mathrm{L}), \quad$ September/10 $(4.44 \pm 3.96 \mu \mathrm{g} / \mathrm{L})$, February/11 $(2.65 \pm 2.38 \mu \mathrm{g} /$ $\mathrm{L})$, and July/10 $(2.22 \pm 0.81 \mu \mathrm{g} / \mathrm{L})$. For Ubatuba, the highest mean values were recorded in March/11 $(1.67 \pm 0.38 \mu \mathrm{g} / \mathrm{L}), \quad$ June $/ 11 \quad(1.50 \pm 0.28 \mu \mathrm{g} / \mathrm{L})$, September/10 $(0.80 \pm 0.40 \mu \mathrm{g} / \mathrm{L})$, and August $/ 10$ $(0.78 \pm 0.32 \mu \mathrm{g} / \mathrm{L})$. The highest means of chlorophyll- $a$ were recorded in the same months in which the lowest mean temperatures were recorded, for both regions.

The mean organic-matter content in the sediment at Macaé was $9.04 \pm 3.49 \%$, ranging from 2.53 to $14.63 \%$. For Ubatuba, the lowest mean organic-matter content was $2.81 \pm 3.16 \%$, ranging from 0.74 to $11.00 \%$.

Population structure and comparison of the size of the seabob Xiphopenaeus kroyeri (Heller, 1862) between regions

For the analyses, 6,780 individuals from Macaé (3,147 males and 3,633 females) and 4,015 individuals from Ubatuba (1,799 males and 2,216 females) were examined.

The maximum size of the individuals at Macaé was higher than at Ubatuba (Fig. 3). The carapace length (CL) of males at Macaé ranged from 6.9 to $32.2 \mathrm{~mm}$ $(18.5 \pm 4.0 \mathrm{~mm})$, while at Ubatuba the CL ranged from 8.5 to $28.1 \mathrm{~mm}(16.9 \pm 3.2 \mathrm{~mm})$. For females, the CL ranged from 6.0 to $37.9 \mathrm{~mm}(19.2 \pm 6.0 \mathrm{~mm})$ at Macaé and from 7.5 to $34.5 \mathrm{~mm}(17.5 \pm 4.4 \mathrm{~mm})$ at Ubatuba. The mean size (CLmm) of both sexes differed significantly between the two regions (MannWhitney Rank Sum Test, $P<0.001)$. 
Fig. 2 Mean monthly values, standard deviation, maximum values of surface and bottom water temperature in the regions of Macaé and Ubatuba, from July 2010 to June 2011 and minimum and

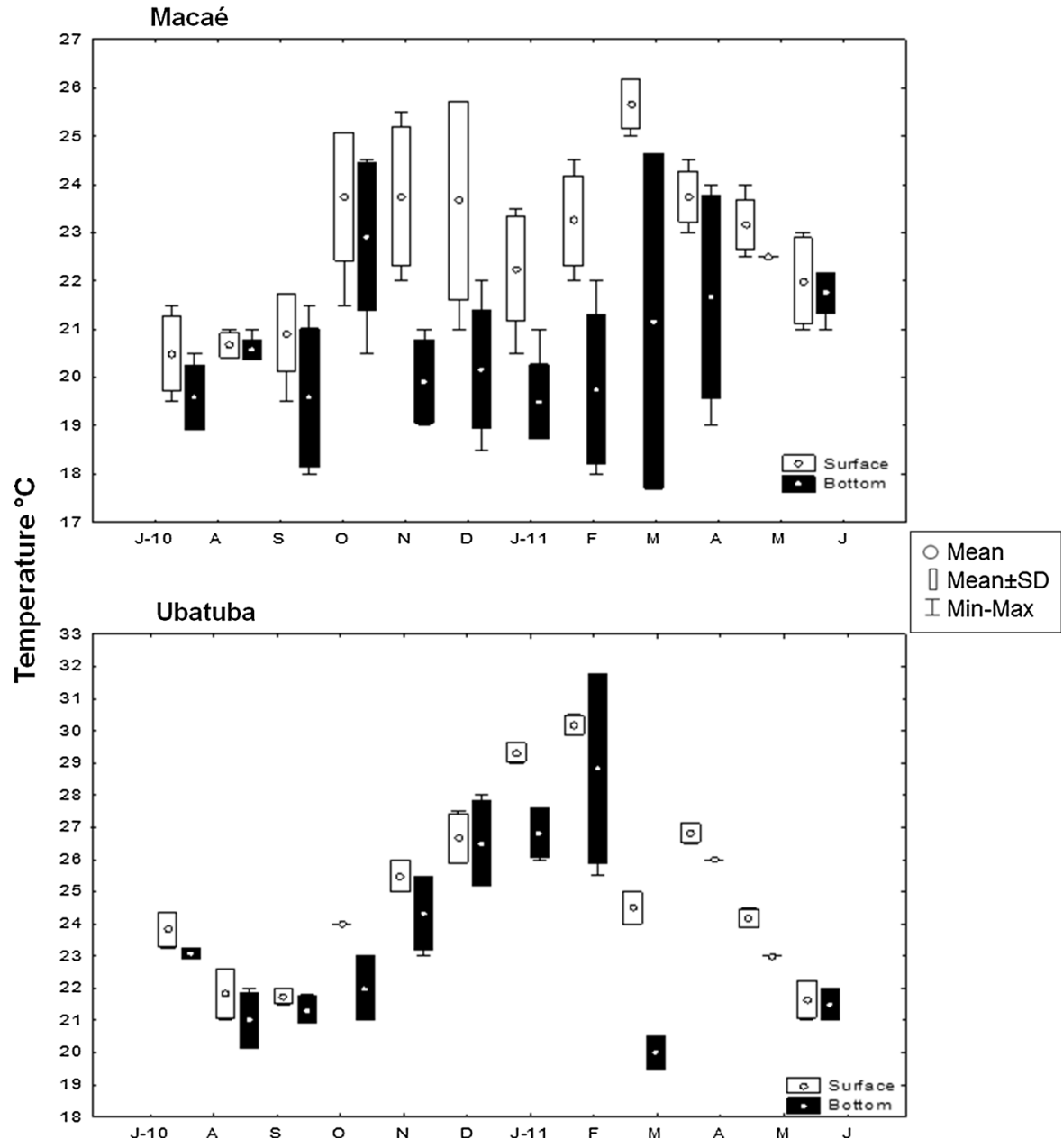

When juveniles and adults were analyzed separately, statistically significant differences were observed between the populations (Mann-Whitney Rank Sum Test, $P<0.001)$. Both populations showed a statistically significant difference in mean size when males and females of the same region were compared (Mann-Whitney Rank Sum Test, $P<0.001$ ). The minimum and maximum sizes (CLmm) found for each demographic class are listed in Tables 1 and 2.

At Macaé, males in the size class (CL) between 18.0 and $19.0 \mathrm{~mm}$ were most frequent. For females, the class between 20.0 and $21.0 \mathrm{~mm}$ was most frequent. At Ubatuba, males and females between 16.0 and $17.0 \mathrm{~mm}$ were most frequent (Fig. 3).

Growth of individuals and longevity

For the population of X. kroyeri at Macaé, six cohorts were identified for males and seven for females. For the population at Ubatuba, five cohorts were identified for males and eight for females. The growth parameters $( \pm 95 \% \mathrm{CL})$ estimated for males collected at Macaé were $k=0.008 \mathrm{~mm} / \mathrm{day}^{-1}, t_{0}=-0.10$, $\mathrm{CL}=31.62 \mathrm{~mm} ; \quad$ and for females, $k=$ $0.007 \mathrm{~mm} / \mathrm{day}^{-1}, t_{0}=-0.53, \mathrm{CL}=38.24 \mathrm{~mm}$. For the population at Ubatuba, the growth parameters $( \pm 95 \% \mathrm{CL})$ were $k=0.012 \mathrm{~mm} / \mathrm{day}^{-1}, t_{0}=-0.06$, $\mathrm{CL}=27.44 \mathrm{~mm}$, and $k=0.008 \mathrm{~mm} / \mathrm{day}^{-1}, t_{0}=$ $-0.27, \mathrm{CL}=29.28 \mathrm{~mm}$ for males and females, respectively. Differences in growth between males and females were observed in both areas (Macaé: $F_{\text {calc }}=5.02>F_{\text {tab }}=3.10$ and Ubatuba: $F_{\text {calc }}=$ $10.56>F_{\mathrm{tab}}=3.13$ ). The maximum longevity of individuals sampled at Macaé was estimated as 1.47 years for males and 1.78 years for females (Fig. 4). For Ubatuba, values were 1.04 years for males and 1.50 years for females (Fig. 5). 
Fig. 3 Xiphopenaeus kroyeri (Heller, 1862). Frequency distribution of the size classes (CLmm) of males and females in Macaé and Ubatuba from July 2010 to June 2011

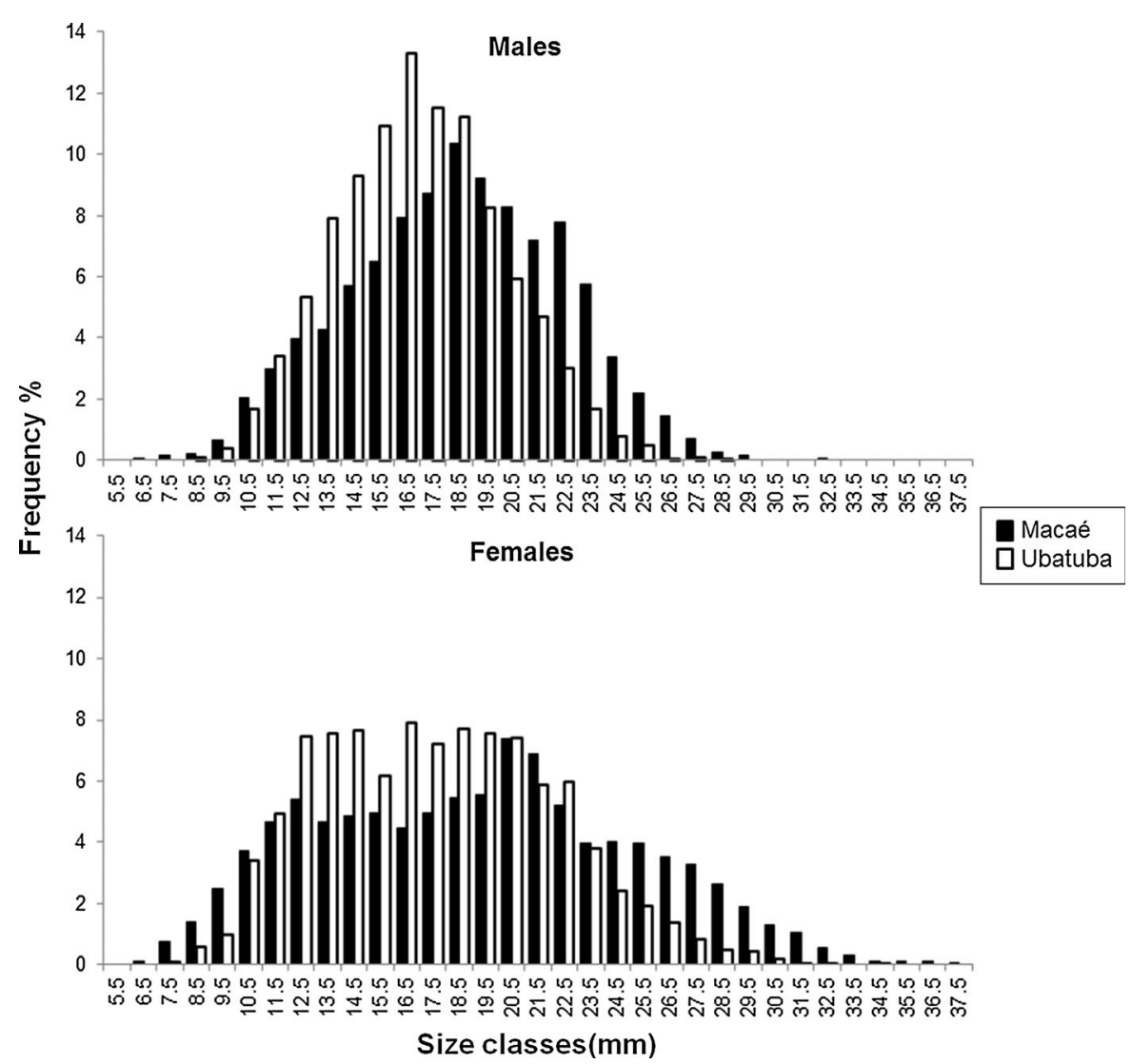

Table 1 Xiphopenaeus kroyeri (Heller, 1862). Descriptive statistics for each demographic category in Macaé/RJ. JM juvenile male, AM adult male, RM reproductive male; JF juvenile female, AF adult female, RF reproductive female

\begin{tabular}{lrcc}
\hline Category demographic & $\mathrm{N}$ & Min-max (CLmm) & Mean \pm SD \\
\hline JM & 342 & $6.9-15.3$ & $11.8 \pm 1.5$ \\
AM & 2805 & $10.0-32.2$ & $19.3 \pm 3.4$ \\
RM & 1365 & $12.4-32.2$ & $20.6 \pm 3.1$ \\
JF & 599 & $6.0-14.4$ & $10.8 \pm 1.6$ \\
AF & 3034 & $11.1-37.9$ & $20.9 \pm 5.1$ \\
RF & 960 & $13.7-37.9$ & $23.9 \pm 4.0$ \\
\hline
\end{tabular}

Reproductive period and recruitment

Reproductive males and females were captured throughout the study period in both regions. However, the percentage of reproductive females in relation to the total of adult females was higher in autumn and winter at Macaé, and in spring and summer at Ubatuba (Fig. 6). In these seasons, the highest percentages were observed in April/11 and September/10 at Macaé, and in December/10 and January/11 at Ubatuba.
When we compare the percentage of juveniles in the population sampled monthly, the highest recruitment peaks were in winter and spring at Macaé and in summer and autumn at Ubatuba. Considering seasons, the reproductive period followed by recruitment is shown in Fig. 6.

Each month, reproductive females in Macaé showed a negative correlation with juveniles in a later month (Time Series, $P<0.05)$. In Ubatuba, this correlation occurred at time zero (Time Series, $P<0.05$ ) (Fig. 7). 
Table 2 Xiphopenaeus kroyeri (Heller, 1862). Descriptive statistics for each demographic category in Ubatuba/SP. JM juvenile male, AM adult male, RM reproductive male, JF juvenile female, AF adult female, RF reproductive female

\begin{tabular}{lrrr}
\hline Category demographic & $\mathrm{N}$ & Min-max $($ CLmm) & Mean \pm SD \\
\hline JM & 247 & $8.5-14.9$ & $12.3 \pm 1.3$ \\
AM & 1552 & $9.7-28.1$ & $17.6 \pm 2.7$ \\
RM & 1132 & $11.3-28.1$ & $18.3 \pm 2.6$ \\
JF & 264 & $7.5-13.9$ & $11.3 \pm 1.2$ \\
AF & 1952 & $9.5-34.5$ & $18.4 \pm 4.0$ \\
RF & 643 & $10.8-34.5$ & $21.7 \pm 3.1$ \\
\hline
\end{tabular}

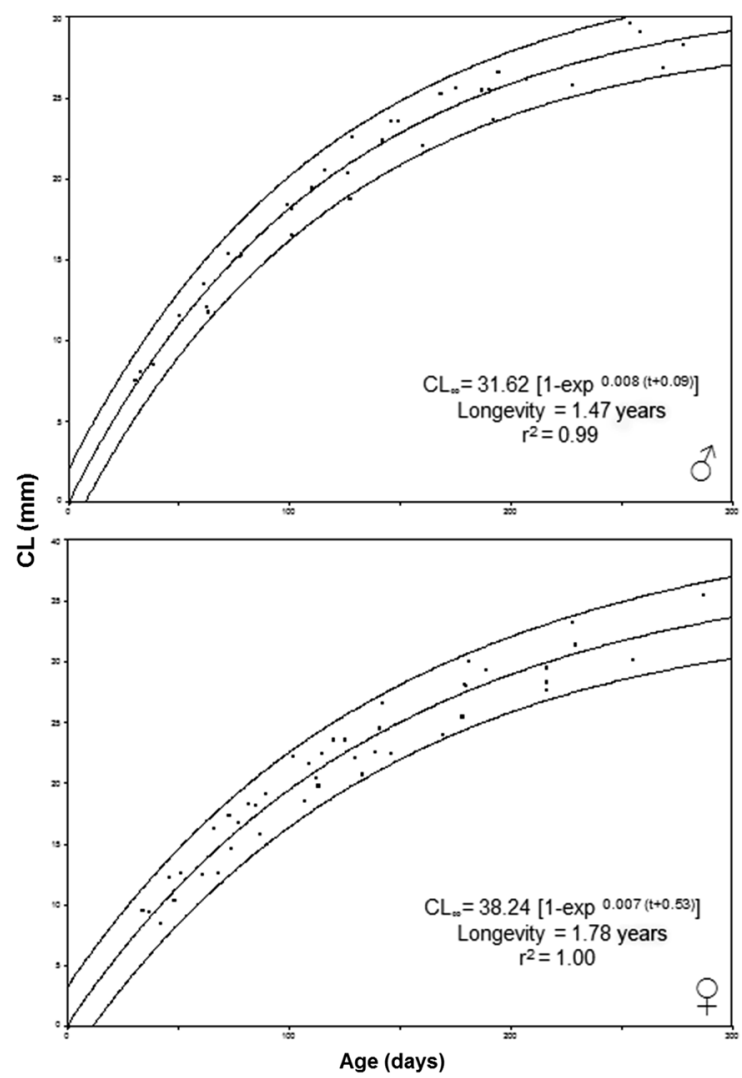

Fig. 4 Xiphopenaeus kroyeri (Heller, 1862). Growth curves and parameters of the von Bertalanffy equation estimated for males and females separately, from July 2010 to June 2011 in Macaé/RJ. The internal line is the average, and the external lines are prediction intervals $(95 \%)$

Environmental factors vs. Juveniles/reproductive females

At Macaé, the number of reproductive females was negatively correlated with the mean organic-matter

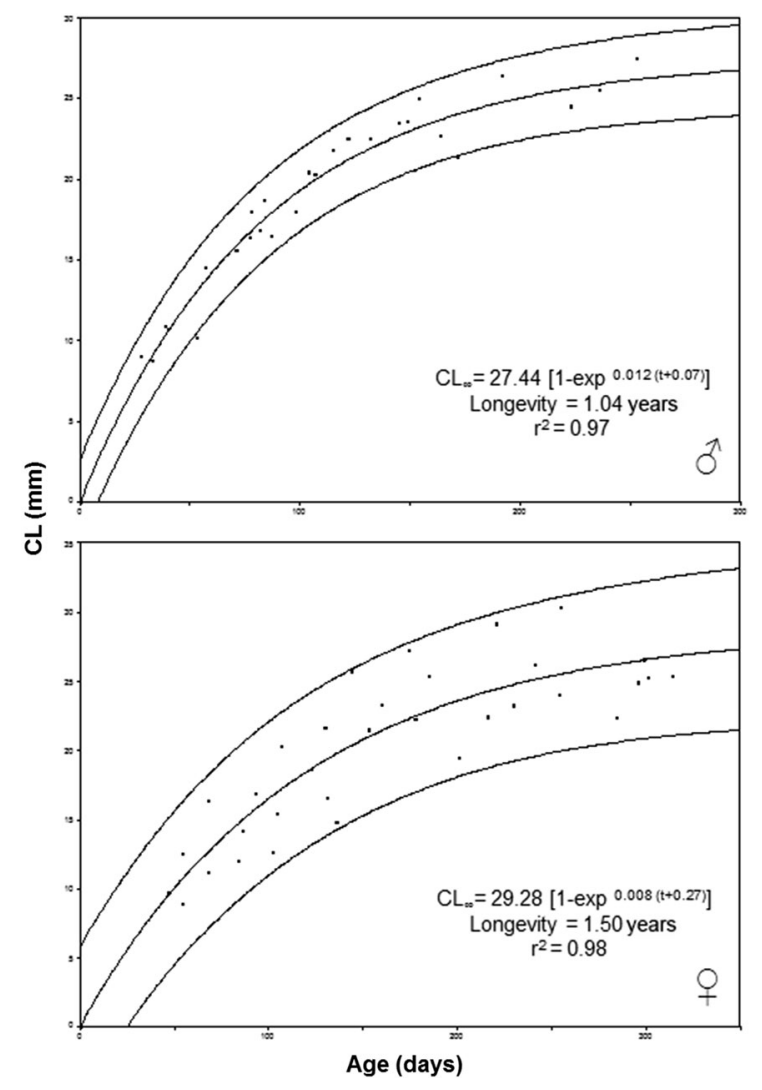

Fig. 5 Xiphopenaeus kroyeri (Heller, 1862). Growth curves and parameters of the von Bertalanffy equation estimated for males and females separately, from July 2010 to June 2011 in Ubatuba/SP. The internal line is the average, and the external lines are prediction intervals $(95 \%)$

content, at time zero until one month later (Time Series, $P<0.05$ ). For juveniles, the correlation was negative with both the mean organic-matter content (one to two months delayed) and mean bottom-water salinity (two months later) (Time Series, $P<0.05$ ). At 
Fig. 6 Xiphopenaeus kroyeri (Heller, 1862). Percentage of reproductive females in relation to the total of adult females; and percentage of juveniles in relation to the total number of individuals sampled monthly in Macaé/RJ and Ubatuba/SP separately. W winter; P spring; S summer; A autumn
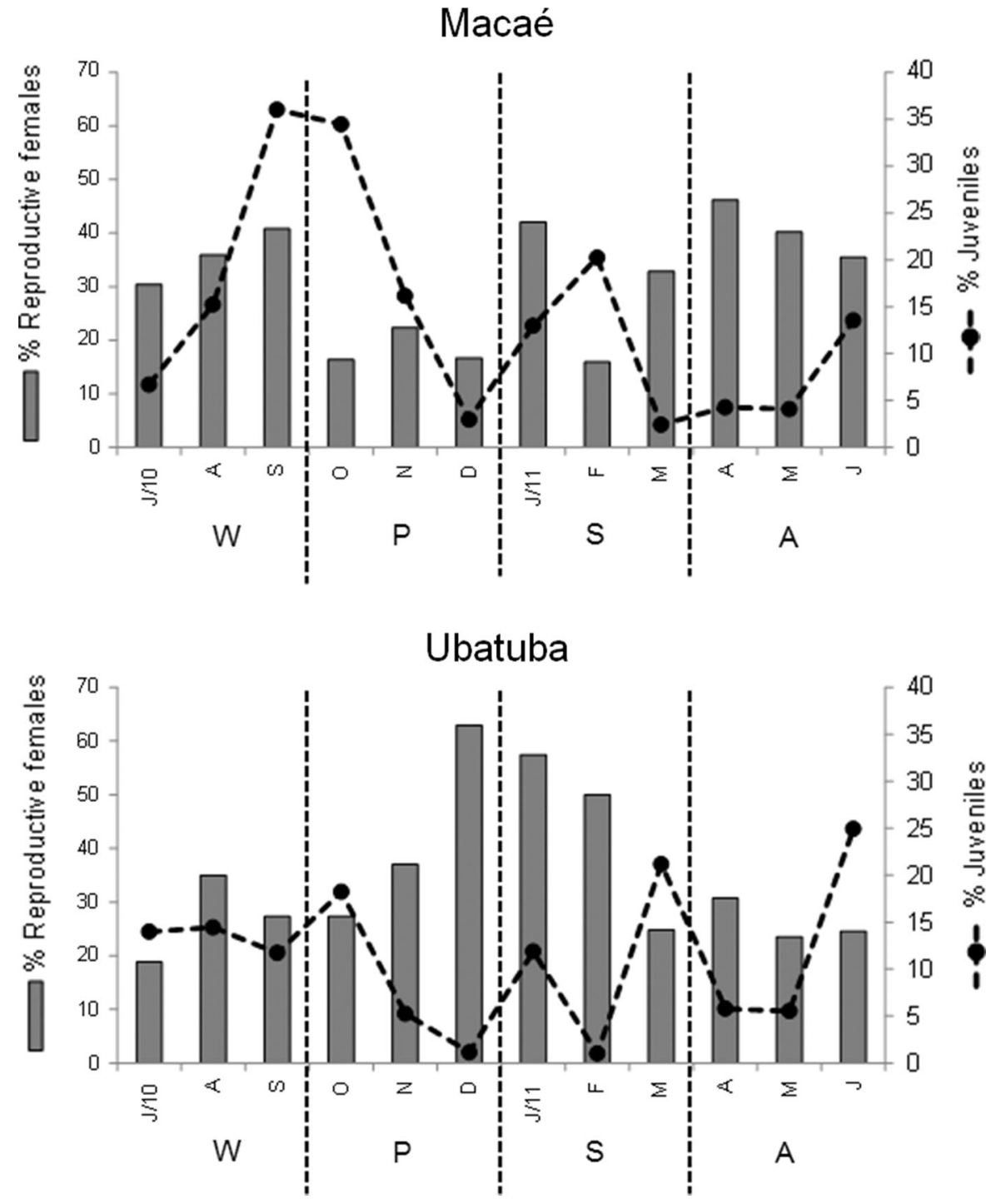

Ubatuba, only a negative correlation between reproductive females and the mean chlorophyll- $a$ was observed, one month after time zero (Time Series, $P<0.05$ ) (Fig. 8).

\section{Discussion}

In a study of three shrimp species of the genus Sicyonia, Bauer (1992) found a relationship between increasing latitude and longevity, and also with the increase in size at which individuals reach sexual maturity. In the same study, Bauer observed that the tropical sicyonid reproduced continuously, and the other two sicyonids (from subtropical and temperate regions) reproduced discontinuously. The "paradigm of the latitudinal effect," which postulates that the population dynamics will change with latitude, applied to these three sicyonid species. This issue was thoroughly discussed in several studies with penaeid shrimps (Bauer, 1992; Costa \& Fransozo, 2004; Castilho et al., 2007b; Costa et al., 2010).

In the present study, we observed the opposite pattern in relation to size (CLmm). Comparison of the two regions showed that individuals of both sexes from the lower-latitude Macaé reached larger sizes and greater longevities than those from Ubatuba. 


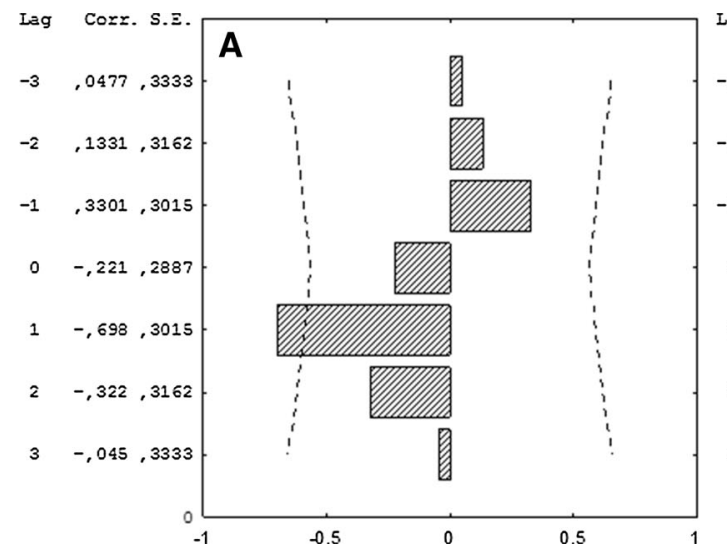

Fig. 7 Xiphopenaeus kroyeri (Heller, 1862). Time-series analysis from July 2010 to June 2011. Macaé/RJ: (A reproductive and juvenile females) and Ubatuba/SP: (B reproductive and

Although the latitudinal difference between these two regions is only approximately $1^{\circ}$, the environmental factors in each study area proved to be very different. The influence of the SACW is one of the main factors producing the temperature decrease and the increase in local primary productivity, by bringing nutrients (such as $\mathrm{P}$ and $\mathrm{N}$ ) into the photic zone (Valentin, 1984), especially at Macaé near the Cabo Frio (RJ) upwelling. Our results concord with this information, as chlorophyll- $a$ concentrations were higher at Macaé than at Ubatuba. The paradigm of the latitudinal effect could not be observed in this study, due to these peculiarities of the lower-latitude region (Macaé).

According to Bergmann's rule, originally proposed for endothermic (Bergmann, 1847) and subsequently for heterothermic organisms (Lukin, 1940; Mina \& Klevezal, 1976; Cushman et al., 1993; Hawkins \& Lawton, 1995; Timofeev, 2001), temperature is directly related to the larger body sizes of animals from cold regions compared to animals from warm regions (Bergmann, 1847).

Additionally to this principle, the difference in temperature between the two regions may have affected the maximum and mean sizes observed for the shrimp at Macaé, compared to Ubatuba. This difference in size probably results from the increased growth of cell size during the development of individuals in the Macaé region. This characteristic was observed in heterothermic animals from cold regions compared to animals from warm regions (Van Voorhies, 1996). This larger size of the cells is directly

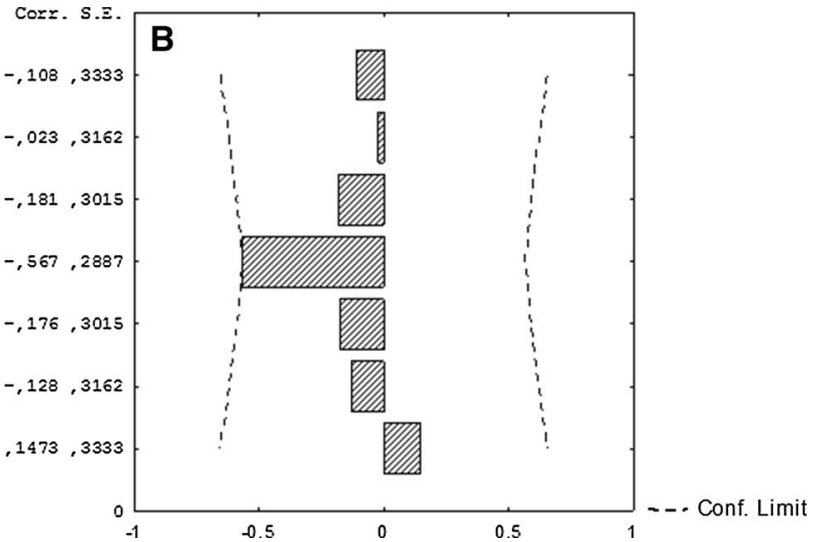

juvenile females). Lag: time; Corr correlation value, SE standard error, Conf. Limit confidence limit

related to a larger genome, for structural reasons (Cavalier-Smith, 1985). A positive correlation between genome size and body size was observed for other invertebrates, for example Aedes albopictus (Skuse, 1894) (Ferrari \& Rai, 1989).

Some studies support our results for the difference in mean sizes of $X$. kroyeri between the two populations. Kumar \& Rai (1990) found variations in the DNA content (0.62-1.66 pg) for different geographical populations of A. albopictus. According to McLaren et al. (1988), a variation in the genome size at the intraspecific level may occur as a result of environmental factors. In a study of fish and syngeneic nematodes, Van Voorhies (1996) observed an increase in cell size and consequently in body size, for organisms grown at low temperatures. Van Voorhies (1996) emphasized that the larger size of heterothermic individuals at low temperatures is directly related to cell growth. In support of this idea, Partridge et al. (1994) observed an increase in the wing size of Drosophila melanogaster Meigen, 1830 grown at low temperatures, compared to populations in higher temperatures. The authors attributed this to the increase in the area of the wing cells of these fruit flies.

The larger sizes and greater longevities observed here for females than for males are directly related. Although males and females from Macaé showed similar growth constants, the greater longevity of females extends the growth period, as most crustaceans grow throughout their lives (Vogt, 2012). This characteristic was also observed in two species of amphipods by Koszteyn et al. (1995). This relationship 

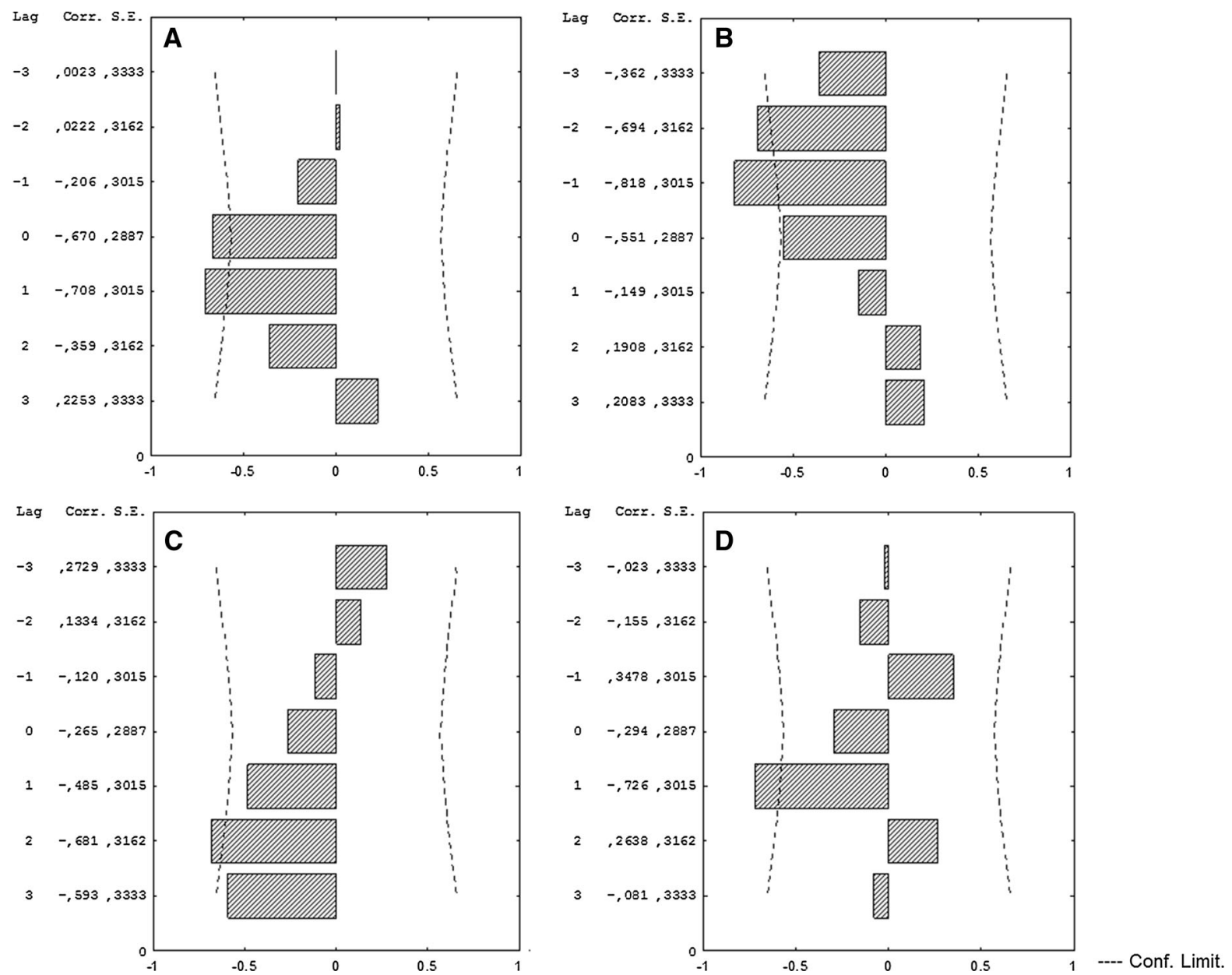

Fig. 8 Xiphopenaeus kroyeri (Heller, 1862). Time-series analysis from July 2010 to June 2011. Macaé/RJ: (A reproductive females and organic matter content, B Juveniles and organic matter content, $\mathbf{C}$ juvenile and bottom salinity) and Ubatuba/SP:

suggests another factor that helps to explain why the size of shrimp differed between regions in the present study. Individuals at Macaé, compared to those at Ubatuba, are longer-lived and consequently reach larger sizes, besides being in cooler waters.

Coastal oceanic upwelling is associated with increased pelagic productivity because the nutrients, which normally limit phytoplankton production, become readily available, often creating phytoplankton blooms despite cooler water temperatures (Reddin et al., 2015). Then, associated productivity and biomass can support higher trophic levels (i.e., 'bottom-up' control) (Menge, 1992; Carr \& Kearns, 2003; Reddin et al., 2015). With increased primary productivity, the populations of herbivorous zooplankton will
(D reproductive females and chlorophyll-a). Lag: time; Corr correlation value, SE standard error, Conf. Limit confidence limit

increase, promoting secondary production. Benthic invertebrates take primary production advantage and detritus generation in the photic zone (Largier, 1993; Mann \& Lazier, 1996). High food availability attracts nekton organisms transferring the energy to higher trophic levels (Acha et al., 2004).

Greater food availability may also have affected the larger sizes of individuals at Macaé. The upwelling regions of western America and Africa are the most productive areas of the oceans (Smith, 1968). The emergence of the SACW water mass in the Cabo Frio upwelling substantially increases primary production in the region. As primary productivity is directly related to the increase in energy in the trophic web (Schmiegelow, 2004), both juveniles and adults of $X$. 
kroyeri at Macaé had a larger food supply to support their development, than at Ubatuba.

In the present study, this factor is apparent from the relationship of both juveniles and reproductive females from Macaé with the organic-matter concentration in the substrate. The negative correlation between the abundance of juveniles and the organicmatter concentration, with a lag of one to two months, shows the importance of this parameter for juvenile growth; the highest concentration of juveniles probably coincided with the greatest food availability. The negative correlation between the abundance of reproductive females and the organic-matter concentration, but with a lag of a month after this food resource declined, is also a result of energy accumulation. Females of $X$. kroyeri store energy from food to support the development of their oocytes, as found by Kevrekidis \& Thessalou-Legaki (2006) for the penaeid Melicertus kerathurus (Forskål, 1775).

The negative correlation, with a lag of two months, between the abundance of juveniles and the salinity is probably influenced by the time needed for these juveniles to reach sexual maturity. Considering that the juvenile phase lasted 63.5 days on average, the period of highest salinity occurred simultaneously with the greatest abundance of juveniles, and two months after this event, the juveniles had matured. As the species, however, has a life cycle totally independent of estuaries (Castro et al., 2005; Costa et al., 2011), adults also do not require low salinities. The higher concentration of salts in the water helps the juvenile integument to harden within a short time period, considering that juveniles have shorter intermolt periods than adults (Vogt, 2012). Studies on crustaceans have shown that difficulties in acquiring calcium and organic supplements to harden a new exoskeleton may increase the mortality rate (Adiyodi \& Adiyodi, 1970; Lima \& Oshiro, 2006).

At Ubatuba, the SACW generally emerges in spring and summer, and is one of the factors responsible for modifying environmental features, mainly by decreasing both temperature $\left(<20^{\circ} \mathrm{C}\right)$ and salinity $(<34)$ (Castro-Filho et al., 1987). The area is considered an oligo-mesotrophic region during the remainder of the year (Costa \& Fransozo, 2004). The emergence of the SACW also contributes to increase the local primary productivity (Valentin, 1984), being responsible for the higher chlorophyll- $a$ concentrations in specific months. At Ubatuba, the negative correlation, with a lag of one month, between the chlorophyll- $a$ concentration and reproductive females may be related to an adjustment of the $X$. kroyeri population to spawn in the most favorable period for larval survival. According to Sastry (1983), temperature is a proximate factor, as it affects both the beginning and the end of a reproductive season; primary production is considered a late factor, because food availability in the larval phase is decisive in the selection of this period by decapods (Thorson, 1950; Sastry, 1983; Bauer \& Lin, 1994; Koeller et al., 2009).

The occurrence of reproductive individuals throughout the year is a characteristic of continuously reproducing organisms. The populations of $X$. kroyeri analyzed here, however, showed an asynchronous reproductive period: although the population as a whole was reproducing throughout the year, not all adults were actively reproducing in all periods (Bauer, 1989). The different peaks of reproductive females during the year indicate this type of reproductions.

A negative correlation, with a lag of one month, between decreases in the abundance of reproductive females and increases in the abundance of juveniles was observed for the population at Macaé. As a result, the highest recruitment peaks in late winter and early spring were related to higher peaks of reproductive females in autumn and winter. The recruitment peak in summer is probably related to an adjustment of reproductive females, observed in late spring, to the greater intensity of the SACW in summer. This water mass increases the production of phytoplankton, which serve as food for larval recruitment.

For Ubatuba, the highest recruitment peaks in late summer and autumn were related to higher peaks of reproductive females in spring and summer. Considering the negative correlation, with no lag, between the decreased abundance of reproductive females and the increased abundance of juveniles, however, the recruitment period in this region seems to be ineffective, or other reproductive/recruitment areas may exist. With respect to the peaks of reproductive females in the different years of sampling (2005-2007), Heckler et al. (2013) found similar results for the species in this same region, which indicates that the reproductive period of $X$. kroyeri may show a consistent pattern at Ubatuba.

In both regions, the recruitment peak observed in June is probably related to the offseason. Off southeastern and southern Brazil, the offseason period 
extends from March through May each year; this "rest" in the exploitation of seabob shrimp results in more effective recruitment after a spawning period.

The results found in the present study suggest that an adjustment in the offseason period for X. kroyeri is desirable. Local environmental factors resulted in differences in some aspects of the dynamics of $X$. kroyeri between the two areas studied. At Macaé, although the current offseason protects a reproductive peak, the smaller recruitment peaks are concentrated in this period. First, adjusting the offseason to extend between August and October would be viable for the seabob shrimp population of Macaé. For the shrimp Artemesia longinaris Spence Bate, 1888, another commercially important penaeid in the area, Sancinetti et al. (2014) suggested an offseason between November and January. The present data show a clear segregation of these two species in different depths, with $X$. kroyeri inhabiting shallower areas and $A$. longinaris inhabiting deeper waters, over $15 \mathrm{~m}$ (Sancinetti et al., 2014). Therefore, an offseason differentiated by fishing area would be the most suitable for both species in the Macaé region.

In Ubatuba, the current offseason protects a recruitment peak and a small peak of reproductive females. The inclusion of January, February (present study and Castilho et al., 2015), and June (present study and Costa et al., 2011) in the current offseason would be ideal. Extending the offseason period to six months (January to June), however, is impractical for the fishing community. Thus, considering the results of the present study and comparing with those of Heckler et al. (2013) and Castilho et al. (2015), we strongly suggest that February be included in the current offseason period. With February included, both the recruitment peak and a larger number of reproductive females would be protected.

The shrimp offseason was defined in order to protect juvenile pink shrimp (Farfantepenaeus spp.). Considering the economic importance of seabob shrimp, we suggest different offseason periods in the two study areas, which will result in more sustainable shrimp harvesting. Our study also showed the different environmental factors between these regions, although they are located close together. This difference in environmental factors, a result of the Cabo Frio upwelling, directly influences the population dynamics of X. kroyeri.

\section{Conclusion}

The influence of the tropical area upwelling in the $X$. kroyeri population deconstructed the latitudinal patterns of size, sexual maturity, and longevity. The two regions' comparison showed that individuals from the lower-latitude Macaé reached larger sizes and greater longevities than the individuals from Ubatuba. The upwelling influenced the reproduction resulting in different times of spawning.

Consequently, such facts were relevant because the results suggest that an adjustment in the offseason period for X. kroyeri in the Macaé region. Local environmental factors resulted in differences in some aspects of the dynamics of $X$. kroyeri between the two areas studied. At Macaé, an adjustment of the offseason between August and October would be viable for seabob shrimp. However, at Ubatuba the period is adequate.

Acknowledgements This work was supported by the "São Paulo Research Foundation" (FAPESP) [\#2009/54672-4]. The authors are grateful to Research Scholarship "Conselho Nacional de Desenvolvimento Científico e Tecnológico" (CNPq) (\#140451/2011-0 to TMD); FAPESP (\#2010/13008-1 to DRH). We thank the LABCAM co-workers for their help during field work and Dr. Alexandre de Azevedo of the Universidade Federal do Rio de Janeiro/NUPEM for the infrastructure to carry out this work. The authors also thank the Dr. Janet W. Reid (JWR Associates) for her great help with English language. All experiments conducted in this study comply with current applicable state and federal laws (Authorization of the Instituto Chico Mendes de Biodiversidade/ICMBio - SISBIO Number 23012-1).

\section{References}

Ab'Saber, A. N., 1955. Contribuição à geomorfologia do litoral paulista. Revista Brasileira de Geologia 17: 3-48.

Acha, E. M., H. W. Mianzan, R. A. Guerrero, M. Favero \& J. Bava, 2004. Marine fronts at the continental shelves of austral South America: physical and ecological processes. Journal of Marine systems 44: 83-105.

Adiyodi, K. G. \& R. G. Adiyodi, 1970. Endocrine control of reproduction in Decapoda Crustacea. Biological Reviews 45: 121-165.

Ávila-da-Silva, A. O., M. H. Carneiro, J. T. Mendonça, G. J. M. Servo, G. C. C. Bastos, S. Okubo-da-Silva \& P. A. Batista, 2005. Produção Pesqueira Marinha do Estado de São Paulo no ano 2004. Série de Relatórios Técnicos do Instituto de Pesca 20: 1-40.

Bauer, R. T., 1989. Continuous reproduction and episodic recruitment in nine shrimp species inhabiting a tropical sea 
grass meadow. Journal of Experimental Marine Biology and Ecology 127: 175-187.

Bauer, R. T., 1992. Testing generalizations about latitudinal variation in reproduction and recruitment patterns with sicyoniid and caridean shrimp species. Invertebrate Reproduction \& Development 22: 193-202.

Bauer, R. T. \& J. Lin, 1994. Temporal patterns of reproduction and recruitment in populations of the penaeid shrimps Trachypenaeus similis (Smith) and T. constrictus (Stimpson) (Crustacea: Decapoda) from the north-central gulf of México. Journal of Experimental Marine Biology and Ecology 182: 205-222.

Bauer, R. T. \& L. W. Rivera-Vega, 1992. Patterns of reproduction and recruitment in two sicyoniid shrimp species (Decapoda: Penaeoidea) from a tropical seagrass habitat. Journal of Experimental Marine Biology and Ecology 161: 223-240.

Bergmann, C., 1847. Über die verhältnisse der wärmeökonomie der thiere zu ihrer grösse. Göttinger Studien 3: 595-708.

Birkeland, C. \& P. K. Dayton, 2005. The importance in fishery management of leaving the big ones. Trends in Ecology \& Evolution 20: 356-358.

Boschi, E. E. \& M. A. Scelzo, 1977. Desarrollo larval y cultivo del camarón comercial de Argentina Artemesia longinaris. FAO Informe de Pesca 159: 287-327.

Branco, J. O. \& H. A. A. Fracasso, 2004. Ocorrência e abundância da carcinofauna acompanhante na pesca do camarão sete-barbas, Xiphopenaeus kroyeri Heller (Crustacea, Decapoda), na Armação do Itapocoroy, Penha, Santa Catarina, Brasil. Revista Brasileira de Zoologia 21: 295-301.

Branco, J. O., M. J. Lunardon-Branco, F. X. Souto \& C. R. Guerra, 1999. Estrutura populacional do camarão setebarbas Xiphopenaeus kroyeri (Heller, 1862), na foz do rio Itajaí-Açu, Itajaí, SC, Brasil. Brazilian Archives of Biology and Technology 42: 115-126.

Brasil, R., 1983. Levantamento de recursos naturais. In Folhas SF.23/24 Rio de Janeiro/Vitoria: geologia, geomorfologia, pedologia, vegetação, uso potencial da terra. Ministério das Minas e Energia, Rio de Janeiro.

Campos, B. R., L. F. C. Dumont, F. D'Incao \& J. O. Branco, 2009. Ovarian development and length at first maturity of the sea-bob-shrimp Xiphopenaeus kroyeri (Heller) based on histological analysis. Nauplius 17: 9-12.

Carr, M. E. \& E. J. Kearns, 2003. Production regimes in four eastern boundary current systems. Deep-Sea Res Pt II. 50: 3199-3221.

Castilho, A. L., A. Fransozo, R. C. Costa \& E. E. Boschi, 2007a. Reproductive pattern of the South American endemic shrimp Artemesia longinaris (Decapoda, Penaeoidea), off São Paulo State, Brazil. Revista de Biologia Tropical 55: 39-48.

Castilho, A. L., M. A. Gavio, R. C. Costa, E. E. Boschi, R. T. Bauer \& A. Fransozo, 2007b. Latitudinal variation in population structure and reproductive pattern of the endemic South American shrimp Artemesia longinaris (Decapoda: Penaeoidea). Journal of Crustacean Biology 27: $548-552$.

Castilho, A. L., M. R. Pie, A. Fransozo, A. P. Pinheiro \& R. C. Costa, 2008. The relationship between environmental variation and species abundance in shrimp community
(Crustacea: Decapoda: Penaeoidea) in south-eastern Brazil. Journal of Marine Biology 88: 119-123.

Castilho, A. L., R. T. Bauer, F. A. M. Freire, V. Fransozo, R. C. Costa, R. C. Grabowski \& A. Fransozo, 2015. Lifespan and reproductive dynamics of the commercially important seabob shrimp Xiphopenaeus kroyeri (Penaeoidea): synthesis of a 5-year study. Journal of Crustacean Biology 35: 30-40.

Castro, R. H., R. C. Costa, A. Fransozo \& F. L. M. A. Mantelatto, 2005. Population structure of seabob shrimp Xiphopenaeus kroyeri (Heller, 1862) (Crustacea: Penaeoidea) in the littoral of São Paulo. Scientia Marina 69: 105-112.

Castro-Filho, B. M., L. B. Miranda \& S. Y. Myao, 1987. Condições hidrográficas na plataforma continental ao largo de Ubatuba: variações sazonais e em média escala. Boletim do Instituto Oceanográfico 35: 135-151.

Cavalier-Smith, T., 1985. Cell volume and the evolution of eukaryotic genome size. In Cavalier-Smitht, T. (ed.), The Evolution of Genome Size. Wiley, Chichester: 105-184.

Costa, R. C. \& A. Fransozo, 2004. Reproductive biology of the shrimp Rimapenaeus constrictus (Stimpson, 1874) (Crustacea, Decapoda, Penaeidae) in Ubatuba region, SP, Brazil. Journal of Crustacean Biology 24: 274-281.

Costa, R. C., A. Fransozo, F. L. M. Mantelatto \& R. H. Castro, 2000. Occurrence of shrimp species (Crustacea: Decapoda: Natantia: Penaeidea and Caridea) in Ubatuba Bay, Ubatuba SP, Brazil. Proceedings of the Biological Society of Washington 113: 776-781.

Costa, R. C., A. Fransozo, G. A. S. Melo \& F. A. M. Freire, 2003. An illustrated key for Dendrobranchiata shrimps from the northern coast of São Paulo state, Brazil. Biota Neotropica 3: 1-12.

Costa, R. C., A. Fransozo, F. A. M. Freire \& A. L. Castilho, 2007. Abundance and ecological distribution of the "setebarbas" shrimp Xiphopenaeus kroyeri (Heller, 1862) (Decapoda: Penaeoidea) in three bays of the Ubatuba region, South-eastern Brazil. Gulf and Caribbean Research 19: 33-41.

Costa, R. C., J. O. Branco, I. F. Machado, B. R. Campos \& M. G. Avila, 2010. Population biology of shrimp Artemesia longinaris Bate, 1888 (Crustacea, Decapoda, Penaeidae) from the south coast of Brazil. Journal of the Marine Biological Association of the United Kingdom 90: 663-669.

Costa, R. C., G. S. Heckler, S. M. Simões, M. Lopes \& A. L. Castilho, 2011. Seasonal variation and environmental influences on abundance of juveniles of the seabob shrimp Xiphopenaeus kroyeri (Heller, 1862) in southeastern Brazil. In Pessani, D., T. Tirelli \& C. Froglia (eds), Monograph series "Atti di Convegni" of the Ninth Colloquium Crustacea Mediterranea. Grafica Ferrieri, Torino: 47-58.

Cushman, J. H., J. H. Lawton \& B. F. J. Manly, 1993. Latitudinal patterns in Europe ant assemblages: variation in species richness and body size. Oecologia 95: 30-37.

De Leo, F. C. \& A. M. S. Pires-Vanin, 2006. Benthic megafauna communities under the influence of the South Atlantic Central Water intrusion onto the Brazilian SE shelf: a comparison between an upwelling and a non-upwelling ecosystem. Journal of Marine Systems 60: 268-284. 
De Pesca, Instituto, 2012. Estatística pesqueira. Ministério da Pesca e Aquicultura, Brasília.

D'Incao, F. \& D. B. Fonseca, 1999. Performance of the von Bertalanffy growth curve in penaeid shrimps: a critical approach. In Klein, J. C. Von \& F. R. Schram (eds), The Biodiversity Crisis and Crustacea: Proceedings of the Fourth International Crustacean Congress. A. A. Balkema, Rotterdam: 733-737.

Emilsson, I., 1961. The shelf and coastal waters of Southern Brazil. Boletim do Instituto Oceanográfico 11: 101-112.

Fernandes, L. P., A. C. Silva, L. P. Jardim, K. A. Keunecke \& A. P. M. Di Beneditto, 2011. Growth and recruitment of the Atlantic seabob shrimp, Xiphopenaeus kroyeri (Heller, 1862) (Decapoda, Penaeidae), on the coast of Rio de Janeiro, Southeastern Brazil. Crustaceana 84: 1465-1480.

Ferrari, J. A. \& K. S. Rai, 1989. Phenotypic correlates of genome size variation in Aedes albopictus. Evolution 43: 895-899.

FIPERJ, 2015. Relatório da Fundação Instituto de Pesca do Estado do Rio de Janeiro. FIPERJ, Niterói.

Fonteles-Filho, A. A., 2011. Oceanografia, biologia e dinâmica populacional de recursos pesqueiros. Expressão Gráfica e Editora, Fortaleza.

Freire, F. A. M., A. C. Luchiari \& V. Fransozo, 2011. Environmental substrate selection and daily habitual activity in Xiphopenaeus kroyeri shrimp (Heller, 1862) (Crustacea: Penaeioidea). Indian Journal of Marine Science 40: 325-330.

Gaeta, S. A. \& F. P. Brandini, 2006. Produção primária do fitoplâncton na região entre o Cabo de São Tomé (RJ) e o Chuí (RS). In Rossi-Wongtschowski, C. L. D. B. \& L. S. Madureira (eds), O Ambiente oceanográfico da Plataforma Continental e do Talude na Região Sudeste-Sul do Brasil. EDUSP, São Paulo: 219-264.

Gavio, M. A. \& E. E. Boschi, 2004. Biology of the shrimp Artemesia longinaris Bate, 1888 (Crustacea: Decapoda: Penaeidae) from Mar del Plata coast, Argentina. Nauplius 12: 83-94.

Golterman, H. L., R. S. Clymo \& M. A. Ohnstad, 1978. Methods for Physical \& Chemical Analysis of Freshwater, 2nd ed. Blackwell Scientific, Oxford.

Gonzalez-Rodriguez, E., J. L. Valentin, D. L. Andre \& S. A. Jacob, 1992. Upwelling and pownwelling at Cabo Frio (Brazil): comparison of biomass and primary production responses. Journal of Plankton Research 14: 289-306.

Gusmão, J., C. Lazoski, F. A. Monteiro \& A. M. Sole-Cava, 2006. Cryptic species and population structuring of the Atlantic and Pacific sea-bob shrimp species, Xiphopenaeus kroyeri and Xiphopenaeus riveti. Marine Biology 149: 491-502.

Hawkins, B. A. \& J. H. Lawton, 1995. Latitudinal gradients in butterfly body sizes: is there a general pattern? Oecologia 102: 31-36.

Heckler, G. S., S. M. Simões, A. P. F. Santos, A. Fransozo \& R. C. Costa, 2013. Population dynamics of the seabob shrimp Xiphopenaeus kroyeri (Dendrobranchiata, Penaeidae) in south-eastern Brazil. South African Journal of Marine Science 35: 17-24.

Heckler, G. S., M. Lopes, S. M. Simoes, R. M. Shimizu \& R. C. Costa, 2014a. Annual, seasonal and spatial abundance of the seabob shrimp Xiphopenaeus kroyeri (Decapoda, Penaeidae) off the Southeastern coast of Brazil. Anais da Academia Brasileira de Ciências 86: 1337-1346.

Heckler, G. S., R. C. Costa, A. Fransozo, S. Rosso \& R. M. Shimizu, 2014b. Long-term patterns of spatial and temporal distribution in a seabob shrimp Xiphopenaeus kroyeri (Decapoda, Penaeidae) population in southeastern Brazil. Journal of Crustacean Biology 34: 326-333.

IBAMA, 2011. Boletim estatístico da aquicultura e pesca no Brasil. Ministério do Meio Ambiente, Brasília.

Kevrekidis, K. \& M. Thessalou-Legaki, 2006. Catch rates, size structure and sex ratio of Melicertus kerathurus (Decapoda: Penaeidae) from an Aegean sea trawl fishery. Fisheries Research 80: 270-279.

Koeller, P., C. Fuentes-Yaco, T. Platt, S. Sathyendranath, A. Richards, P. Ouellet, D. Orr, U. Skúladóttir, K. Wieland, L. Savard \& M. Aschan, 2009. Basin-scale coherence in phenology of shrimps and phytoplankton in the North Atlantic Ocean. Science 324: 791-793.

Koszteyn, J., S. Timofeev, J. M. Weslawski \& B. Malinga, 1995. Size structure of Themisto abyssorum Boeck and Themisto libellula (Mandt) populations in European Artic seas. Polar Biology 15: 85-92.

Kumar, A. \& K. S. Rai, 1990. Intraspecific variation in nuclear DNA content among world populations of a mosquito, Aedes albopictus (Skuse). Theoretical and Applied Genetics 79: 748-752.

Largier, J. L., 1993. Estuarine fronts: how important are they? Estuaries 16: 1-11.

Lima, G. V. \& L. M. Y. Oshiro, 2006. Crescimento somático do caranguejo-uçá Ucides cordatus (Linnaeus) (Crustacea, Brachyura, Ocypodadae) em laboratório. Iheringia Serie Zoologia 96: 467-472.

Lopes, R. M., M. Katsuragawa, J. F. Dias, M. A. Montú, J. H. Muelbert, C. Gorri \& F. P. Brandini, 2006. Zooplankton and ichthyoplankton distribution on the southern Brazilian shelf: an overview. Scientia Marina 70: 189-202.

Lukin, E. I., 1940. Darwinism and Geographic Trends in Variation of Organisms. Akad, Nauk SSSR, Moscow.

Mann, K. H. \& J. R. N. Lazier, 1996. Dynamics of Marine Ecosystems. Biological-Physical Interactions in the Oceans, 2nd ed. Blackwell, Cambridge.

McLaren, I. A., J. M. Srvigny \& C. J. Corbett, 1988. Body sizes, development rates and genome sizes among Calanus species. Hydrobiologia 167: 275-284.

Menge, B. A., 1992. Community regulation: under what conditions are bottom-up factors important on rocky shores? Ecology 73: 755-765.

Mina, M. V. \& G. A. Klevezal, 1976. Growth of Animals. Analysis at the Level of Organism. Nauka, Moscow.

Moreira da Silva, A. D. C., 1977. Upwelling and its biological effects in Southern Brazil. Instituto de Pesquisa Marinha, Rio de Janeiro.

Nakagaki, J. M. \& M. L. Negreiros-Fransozo, 1998. Population biology of Xiphopenaeus kroyeri (Heller, 1862) (Decapoda: Penaeidae) from Ubatuba bay, São Paulo, Brazil. Journal of Shellfish Research 17: 931-935.

Negreiros-Fransozo, M. L., A. Fransozo, M. A. A. Pinheiro, F. L. M. Mantelatto \& S. Santos, 1991. Caracterização física e química da enseada da Fortaleza, Ubatuba, SP. Brazilian Journal of Geology 21: 114-120. 
Odebrecht, C. \& L. Djurfeldt, 1996. The role of nearshore mixing on the phytoplankton size structure off Santa Marta Cape, southern Brazil (Spring 1989). Archive of Fishery and Marine Research 43: 217-230.

Pantaleão, J. A. F., A. Carvalho-Batista, A. Fransozo \& R. C. Costa, 2016. The influence of upwelling on the diversity and distribution of marine shrimp (Penaeoidea and Caridea) in two tropical coastal areas of southeastern Brazil. Hydrobiologia 763: 381-395.

Partridge, L., B. Barrie, K. Fowler \& V. French, 1994. Evolution and development of body size and cell size in Drosophila melanogaster in response to temperature. Evolution 48: 1269-1276.

Reddin, C. J., F. Docmac, N. E. O'Connor, J. H. Bothwell \& C. Harrod, 2015. Coastal upwelling drives intertidal assemblage structure and trophic ecology. PloS ONE 10: 1-20.

Robert, R., C. A. Borzone \& C. D. Natividade, 2007. Os camarões da fauna acompanhante na pesca dirigida ao camarão-sete-barbas (Xiphopenaeus kroyeri) no litoral do Paraná. Boletim do Instituto de Pesca 33: 237-246.

Sancinetti, G. S., A. Azevedo, A. L. Castilho, A. Fransozo \& R. C. Costa, 2014. How marine upwelling influences the distribution of Artemesia longinaris (Decapoda: Penaeoidea)? Latin American Journal of Aquatic Research 42: 322-331.

Sastry, A. N., 1983. Ecological aspects of reproduction. In Vernberg, F. J. \& W. B. Vernberg (eds), The Biology of Crustacea, Environmental Adaptations. Academic Press, New York: 179-270.

Schmiegelow, J. M. M., 2004. O planeta azul, 1st ed. Editora Interciência, Rio de Janeiro.

Semensato, X. E. G. \& A. P. M. Di Beneditto, 2008. Population dynamic and reproduction of Artemesia longinaris (Decapoda, Penaeidae) in Rio de Janeiro State, South-eastern Brazil. Boletim do Instituto de Pesca 34: 89-98.

Severino-Rodrigues, E., D. S. F. Guerra \& R. Graça-Lopes, 2002. Carcinofauna acompanhante da pesca dirigida ao camarão-sete-barbas (Xiphonepaeus kroyeri) desembarcada na praia do Perequê, estado de São Paulo, Brasil. Boletim do Instituto de Pesca 28: 33-48.
Silva, E. R., G. S. Sancinetti, A. Fransozo, A. Azevedo \& R. C. Costa, 2014. Biodiversity, distribution and abundance of shrimps Penaeoidea and Caridea communities in region the vicinity of upwelling in Southeastern of Brazil. Nauplius 22: $1-11$.

Simões, S. M., R. C. Costa, A. Fransozo \& A. L. Castilho, 2010. Diel variation in abundance and size of the seabob shrimp Xiphopenaeus kroyeri (Crustacea, Penaeoidea) in the Ubatuba region, Southeastern Brazil. Anais da Academia Brasileira de Ciências 82: 369-378.

Smith, R. L., 1968. Upwelling. Oceanography and Marine Biology Annual Review 6: 11-46.

StatSoft, Inc., 2004. Statistica (data analysis software system), version 7.

Thorson, G., 1950. Reproductive and larval ecology of marine botton invertebrates. Biological Reviews 25: 1-45.

Timofeev, S. F., 2001. Bergmann's principle and deep-water gigantism in marine crustaceans. The Biological Bulletin 28: $646-650$.

Valentin, J. L., 1984. Analyses des parameters hydrobiologiques dans la remontée de Cabo Frio (Brésil). Marine Biology 82: 259-276.

Van Voorhies, W. A., 1996. Bergmann size clines: a simple explanation for their occurrence in ectotherms. Evolution 50: 1259-1264.

Vogt, G., 2012. Ageing and longevity in the Decapoda (Crustacea): a review. Zoolozischer Anzeiger 251: 1-25.

Voloch, C. M. \& A. M. Sole-Cava, 2005. Genetic structure of the sea-bob shrimp (Xiphopenaeus kroyeri Heller, 1862; Decapoda, Penaeidae) along the Brazilian southeastern coast. Genetics and Molecular Biology 28: 254-257.

Walsh, M. R., S. B. Munch, S. Chiba \& D. Conover, 2006. Maladaptive changes in multiple traits caused by fishing: impediments to population recovery. Ecology Letters 9: 142-148.

Zar, J. H., 1996. Biostatistical Analysis, 3rd ed. Prentice Hall, New Jersey.

Zar, J. H., 1999. Biostatistical Analysis, 4th ed. Prentice Hall, New Jersey. 